medRxiv preprint doi: https://doi.org/10.1101/2020.11.11.20229062; this version posted November 16, 2020. The copyright holder for this preprint (which was not certified by peer review) is the author/funder, who has granted medRxiv a license to display the preprint in It is made available under a CC-BY-NC-ND 4.0 International license.

\title{
Longevity of seropositivity and neutralizing titers among SARS-CoV-2 infected individuals after 4 months from baseline: a population-based study in the province of Trento
}

Paola Stefanelli ${ }^{{ }^{\wedge}}$, Antonino Bella ${ }^{\mathrm{a}}$, Giorgio Fedele ${ }^{\mathrm{a}}$, Stefano Fiore ${ }^{\mathrm{a}}$, Serena Pancheri ${ }^{\mathrm{b}}$, Eleonora Benedetti $^{\mathrm{a}}$, Concetta Fabiani ${ }^{\mathrm{a}}$, Pasqualina Leone ${ }^{\mathrm{a}}$, Paola Vacca ${ }^{\mathrm{a}}$, Ilaria Schiavoni ${ }^{\mathrm{a}}$, Arianna Neri ${ }^{\mathrm{a}}$, Anna Carannante ${ }^{\mathrm{a}}$, Maurizio Simmaco ${ }^{\mathrm{c}}$, Iolanda Santino ${ }^{\mathrm{c}}$, Maria Grazia Zuccali ${ }^{\mathrm{b}}$, Giancarlo Bizzarri $^{\mathrm{b}}$, Rosa Magnoni ${ }^{\mathrm{b}}$, Pier Paolo Benetollo ${ }^{\mathrm{b}}$, Silvio Brusaferro ${ }^{\mathrm{d}}$, Giovanni Rezza ${ }^{\mathrm{e}}$ and Antonio Ferro $^{\mathrm{b}}$

${ }^{a}$ Department Infectious Diseases, Istituto Superiore di Sanità, Italy

${ }^{\mathrm{b}}$ APSS (Azienda Provinciale per i Servizi Sanitari), Trento, Italy

${ }^{\mathrm{c}}$ Hospital Direction and Clinical Departments, Sant'Andrea University Hospital, Italy

${ }^{\mathrm{d}}$ Istituto Superiore di Sanità, Italy

${ }^{\mathrm{e}}$ Health Prevention Directorate, Ministry of Health, Italy

${ }^{\wedge}$ Corresponding author: Dr. Paola Stefanelli, paola.stefanelli@iss.it

\section{Summary}

Background. There are conflicting results about the duration of antibodies induced by SARS-CoV2 , but several studies show a rapid decay in a few months after infection. To evaluate antibody decline, we re-evaluated the presence of anti-SARS-CoV-2 antibodies among individuals found seropositive in a first population survey conducted 4 months before.

Methods. All individuals above ten years of age resident in 5 municipalities of the Autonomous Province of Trento, northern Italy, who resulted IgG positive for anti-SARS-CoV-2 nucleocapsid (NC) antibodies in a serosurvey conducted on May 2020 were retested after 4 months. Anti-SARSCoV-2 antibodies were detected using the Abbott SARS-CoV-2 IgG assay (Abbott Diagnostics, USA) detecting anti-NC antibodies. Samples that gave a negative result were re-tested using the same test plus Liaison SARS-CoV-2 IgG assay (DiaSorin, Italy) to assess anti-spike (S) S1/S2 IgG antibodies. Seroprevalence was calculated as the proportion of positive people on the total number of tested. A neutralizing assay was performed on a subgroup of formerly positives sera using fiftyNOTE: This preprint reports new research that has nat peen certified by peer review and should not be used to guide clinical practice. percent tissue culture infective dose $\left(\mathrm{TC}_{50}\right)$ as endpoint dilution to produce a cytopathic effect in 
medRxiv preprint doi: https://doi.org/10.1101/2020.11.11.20229062; this version posted November 16, 2020. The copyright holder for this preprint (which was not certified by peer review) is the author/funder, who has granted medRxiv a license to display the preprint in

It is made available under a CC-BY-NC-ND 4.0 International license .

$50 \%$ of inoculated Vero E6 cells culture. In all the analyses a $\mathrm{p}$ value $<0.05$ were considered statistically significant. Statistical analysis was performed by STATA version 16.1 (STATA Corp., College Station, Texas, USA).

Findings. Overall, 1159 out of 1402 initially anti-NC seropositive participants were enrolled in the study. Of them, $480(41.1 \%)$ became seronegative for anti-NC IgG antibodies. When 479 negative sera were tested for anti-S IgG, 373 samples (77.9\%) resulted positives. A functional neutralization assay was performed on 106 sera showing high concordance with anti-S antibodies positivity.

Interpretation. A decline of anti-NC IgG values was recorded 4 months after the first evaluation. Worth of note, a high proportion of anti-NC seronegative individuals were positive for anti-spike IgG antibodies, which appear to persist longer and to better correlate with neutralization activity.

\section{Introduction}

The presence of neutralizing antibodies induced by natural infection or by an effective vaccine is likely to be predictive of protection. Thus, whether antibody response to the administration of vaccines may confer protection is still undefined, and cases of reinfection by severe acute respiratory syndrome coronavirus-2 (SARS-CoV-2) have been sporadically reported1.

The duration of the immune response after infection is also under investigation. The duration of protection against infection with common human coronaviruses appears to be rather short ${ }^{2,3}$, and there are studies showing declines in IgG antibodies against SARS-CoV-2 among both symptomatic and asymptomatic individuals ${ }^{4,5}$.

Whether memory-B-cell and T-cell responses may still confer protection in individuals experiencing antibody decline to undetectable levels is unknown ${ }^{6}$. In general, controversies exist on the possibility that SARS-CoV-2 infection induces sustained humoral immune responses in convalescent patients following symptomatic COVID-19 $9^{7-9}$.

The type of antibody response may also play a role. Experimental vaccination against SARS-CoV with NC can induce strong antibody responses that were found to be non-neutralizing ${ }^{10}$. While nonneutralizing antibodies might still exert antiviral activity, for example via the Fc-Fc receptor-based effector function, non-neutralizing NC antibodies may lead to enhanced disease for some vaccine candidates in animal models when neutralizing antibodies are absent ${ }^{10}$. Instead, studies conducted on SARS-CoV-2 and other coronaviruses have shown that the spike protein is the main target for neutralizing antibodies ${ }^{11-13}$. 
medRxiv preprint doi: https://doi.org/10.1101/2020.11.11.20229062; this version posted November 16, 2020. The copyright holder for this preprint (which was not certified by peer review) is the author/funder, who has granted medRxiv a license to display the preprint in

It is made available under a CC-BY-NC-ND 4.0 International license .

Thus, assessing the duration of detectable antibody response and changes in the titer of neutralizing antibodies is an important step in order to better understand their dynamics and to predict the duration of protection against SARS-CoV-2 infection.

In order to evaluate the persistence of SARS-CoV-2 antibodies, we repeated a serosurvey in five municipalities of the Autonomous Province (AP) of Trento, Italy, recruiting those individuals who had resulted positive in a large population-based seroprevalence study conducted 4 months before ${ }^{14}$. Moreover, in a subsample of seropositive participants, the antibody neutralizing titre was also evaluated.

\section{Methods}

Study population and design

As already reported ${ }^{14}$, the study was conducted in 5 municipalities of the AP of Trento, in the northern of Italy, with the highest incidence of COVID-19 confirmed cases.

The Department of Prevention of the Azienda Provinciale per i Servizi Sanitari (APSS) sent a letter of invitation to participate at a second study to all the citizens who resulted to be positive for antiSARS-CoV-2 antibodies in the serosurvey conducted 4 months before, between May 5 and 15, 2020 .

\section{Serum preparation and storage}

Blood samples (5 ml) were collected in Serum Separator Tubes (BD Diagnostic Systems, Franklin Lakes, NJ, USA) and centrifuged at room temperature at $1600 \mathrm{rpm}$ for $10 \mathrm{~min}$. Aliquots were transferred to $2 \mathrm{ml}$ polypropylene, screw cap cryotubes (Sorfa, Zhejiang, China) and immediately frozen at $-20^{\circ} \mathrm{C}$. Frozen sera were then shipped to the Istituto Superiore di Sanità (ISS) as national reference laboratory for COVID-19, in dry ice following biosafety shipment condition. Upon arrival serum samples were immediately stored at $-80{ }^{\circ} \mathrm{C} .{ }^{14}$

\section{SARS-CoV-2 IgG immunoassays for nucleocapsid (NC) and spike (S)}

Two commercial CLIA assays, employing either $\mathrm{NC}$ or $\mathrm{S}$ antigens and designed for high throughput in healthcare settings, were used. In particular, all the serum samples were evaluated by using the Abbott SARS-CoV-2 IgG assay (Abbott Diagnostics, Chicago, IL, USA); sera resulting negative were retested using the DiaSorin Liaison SARS-CoV-2 IgG assay (DiaSorin, Italy). The Abbott Diagnostics anti-NC IgG assay was performed on the Architect i2000SR automated analyser. The analyser automatically calculates SARS-CoV-2 NC IgG antibody concentration 
medRxiv preprint doi: https://doi.org/10.1101/2020.11.11.20229062; this version posted November 16, 2020. The copyright holder for this preprint (which was not certified by peer review) is the author/funder, who has granted medRxiv a license to display the preprint in

It is made available under a CC-BY-NC-ND 4.0 International license .

expressed as an index value. According to the manufacturer's instructions, the results were interpreted considering as positive an index of $\geq 1.4$ and as negative an index of $<1.4$.

The DiaSorin SARS-CoV-2 IgG assay is also a two-step CLIA assay for the detection of IgG antibodies against S1/S2 antigens of SARS-CoV-2. The assay was performed on the LIAISON® XL fully automated chemiluminescence analyzer. The analyser automatically calculates SARSCoV-2 S1/S2 IgG antibody concentrations expressed as arbitrary units (AU/mL). The assay range is up to $400 \mathrm{AU} / \mathrm{mL}$. According to manufacturer's instructions, values $\geq 15 \mathrm{AU} / \mathrm{mL}$ were interpreted as positive, and values $\leq 12 \mathrm{AU} / \mathrm{mL}$ as negative; in case of results falling within an equivocal zone in between $12 \mathrm{AU} / \mathrm{mL}$ and $15 \mathrm{AU} / \mathrm{mL}$, the test was repeated.

\section{SARS-CoV-2 neutralizing antibody assay}

In vitro neutralising activity provides quantitative results as a measure of a functional humoral immune response against SARS-CoV-2. A known amount of SARS-CoV-2 (code 77III, isolated and cultivated at ISS, titre $1 \times 10^{5,4}$; GISAID accession ID: EPI_ISL_412973) was incubated with different dilutions of the serum sample to determine the dilution at which cytopathic effect on Vero E6 cells (ATCC® CRL-1586) is observed in 50\% of infected wells (MN 50\%). The detailed protocol is described below: two-fold serial dilutions of serum samples starting at 1:8 dilution up to 1:512 in cell culture medium EMEM (Sigma) supplemented with $1 \mathrm{X}$ pen/strep and $2 \%$ fetal bovine serum (FBS; Corning) were added to 96 -well plates. The mixture of virus $\left(100 \mathrm{TCID}_{50}\right)$ and serum was incubated at $37^{\circ} \mathrm{C}$ for 1 hour for a total $100 \mu$ l. After this incubation period, a solution of 22,000 cells per well in a total volume of $100 \mu \mathrm{l}$ was added and incubated at $37^{\circ} \mathrm{C}$ for 5 days.

Finally, the neutralization titer was calculated and expressed as the serum dilution capable of reducing the cytopathic effect to 50\% ( $\mathrm{MN} \mathrm{50 \% ).} \mathrm{Positive} \mathrm{and} \mathrm{negative} \mathrm{sera} \mathrm{samples} \mathrm{and} \mathrm{cell}$ culture control together with the virus were added in each test.

\section{Statistical analysis}

The IgG values were summarized by the median and interquartile range (IQR). The differences among IgG values between the first and the second survey were evaluated by the Wilcoxon test. The differences among IgG values between groups (positive versus negative in the second survey) in the first survey were assessed by Mann-Whitney test. The IgG values observed in the first survey were categorised in tree classes: "weak positive" (between 1.4 and 3.0), "medium positive" (between 3.0 and 5.0), and "highly positive" (>5). The McNemar's test was used to compare frequency on paired data. The concordance between anti-NC, anti-S, and TICD50 was evaluated using the Kappa 
medRxiv preprint doi: https://doi.org/10.1101/2020.11.11.20229062; this version posted November 16, 2020. The copyright holder for this preprint (which was not certified by peer review) is the author/funder, who has granted medRxiv a license to display the preprint in It is made available under a CC-BY-NC-ND 4.0 International license .

test $(\mathrm{K}<0.20=$ "poor", $0.20-0.40=$ "fair", 0.40-0.60 = "moderate", $0.60-0.80=$ "good", and $0.80-1.00=$ "very good").

A multivariable logistic regression model was used to determine the relationship between persistent anti-NC IgG in the second serosurvey (positive versus negative) and a set of explanatory variables. The following variables that were significantly associated $(\mathrm{p}<0.10)$ at the univariate analysis were included in the multivariable model: gender, age group, geographical area, presence of symptoms, working in contact with the public and household size, IgG positivity group (weak, medium, high) olfactory and gustatory dysfunctions, fever, weakness, cough, dyspnea, arthralgia, diarrhoea, and abdominal pain and vomit. The likelihood ratio test was used to compare different models.

A subset of anti-NC IgG positive samples was tested with the neutralization test. Assuming a positive proportion of $95 \%$ and precision of 4\%, 106 samples are required with an alpha error of $5 \%$.

In all the analyses a p-value $<0.05$ was considered statistically significant. Statistical analysis was performed by the STATA version 16.1 (STATA Corp., College Station, Texas, USA).

\section{Ethical approval}

Informed consensus for blood collection was obtained from all the participants. The study was approved by the Ethical Committee of the ISS (Prot. PRE BIO CE n.15997, 04.05.2020).

\section{Results}

\section{Participation in the second survey}

Overall, 1159 individuals of the 1402 individuals who resulted seropositive in the first survey $(82.7 \%)$ were enrolled in the study. All age groups were well represented. The proportion of those who were retested ranged between $72.6 \%$ in the age group $20-29$ years and $93.1 \%$ in the age group 60-69 years.

\section{Changes in antibody levels against NC}

Of the 1159 individuals who resulted initially seropositive 480 (41.4\%) seroreverted at the second evaluation. As shown in Figure 1, a statistically significant reduction in the median value was observed in the second survey, from a median of $5.7(\mathrm{IQR}=3.5)$ to $1.9(\mathrm{IQR}=2.8)$ (p-value < 0.0001 using the non-parametric Wilcoxon signed-rank test).

Comparing the median values in the positive and negative groups, those who seroreverted started from a lower average value (median $=3.6 ; \mathrm{IQR}=1.9$ ) compared with those who remained positive 
medRxiv preprint doi: https://doi.org/10.1101/2020.11.11.20229062; this version posted November $16,2020$. The copyright holder for this preprint (which was not certified by peer review) is the author/funder, who has granted medRxiv a license to display the preprint in

It is made available under a CC-BY-NC-ND 4.0 International license .

(median $=7.0 ;$ IQR $=2.3$ ) at the second survey; the difference was statistically significant (MannWhitney test; $\mathrm{p}<0.0001)$.

As shown in Figure 2, when the participants were stratified in three groups in accordance with their anti-NC IgG level at the baseline [i.e., weak positive (with a value between 1.4 and 3), medium positive (between 3 and 5), and high positive (greater than 5)], the median value of the weakly and moderately positive groups decreased below the assay cut-off after 4 months, while the median of the highly positives remained above the cut-off.

\section{Correlation between anti-SARS-CoV-2 IgG against NC and S proteins and neutralization activity}

The samples resulting negative for antibodies against NC in the second study were tested to evaluate the presence of antibodies against the S protein. Since for one sample the available amount of serum was not sufficient for the analysis, 479 available serum samples were tested, and 373 of them $(77.9 \%)$ resulted positive (Figure 3 ).

\section{Comparison between serology and functional neutralization assay}

A subgroup of 106 sera that were positive for anti-NC-IgG at the first testing were tested for anti$\mathrm{NC} \mathrm{IgG,} \mathrm{anti-S} \mathrm{IgG,} \mathrm{and} \mathrm{their} \mathrm{neutralizing} \mathrm{activity} 4$ months after the baseline. Of the 106 sera, 97 $(91.5 \%)$ showed neutralizing activity (TCID50 $\geq 1 / 8)$, and 9 sera $(8.5 \%)$ had a TCID50 titer <1/8; $57(53.8 \%)$ were anti-NC positive and $93(87.7 \%)$ were anti-S positive. (Figure 4).

As shown in Table 1, only 53 sera showing neutralizing activity were anti-NC IgG positive (54.6\%) versus $92(94.8 \%)$ which were anti-S IgG positive. Most of the anti-NC IgG negative sera (41out of 49) were anti-S positive (83.7\%) and 44 had neutralizing activity (89.8\%). Of 93 anti-S positive sera, 92 showed neutralizing activity, confirming a high concordance between anti-S positivity and neutralization activity, as calculated by McNemar's test.

High and significative agreement $(94,3 \%)$ was found between anti-S and $\operatorname{TCID}_{50}(\mathrm{k}=0.70$; $\mathrm{p}<0.0001$ ) (Table 1). To further confirm the concordance, when IgG levels were considered, a good correlation between anti-S and TICD50 was observed (rho-Spearman: 0.84, p < 0.0001) compared with anti-NC/anti-S (rho-Spearman: 0.61, p < 0.0001) and anti-NC/TICD50 (rho-Spearman: 0.56, p $<0.0001)$.

\section{Factors associated with persistent anti-NC IgG after 4 months}

The multivariable logistic regression model showed that age group, gender, anti-NC IgG level in the first serosurvey, and cough were factors associated with the persistence of anti-NC seropositivity (Table 2). In particular, the individuals with high anti-NC IgG levels in the first serosurvey had the 
medRxiv preprint doi: https://doi.org/10.1101/2020.11.11.20229062; this version posted November 16,2020 . The copyright holder for this preprint (which was not certified by peer review) is the author/funder, who has granted medRxiv a license to display the preprint in It is made available under a CC-BY-NC-ND 4.0 International license.

highest probability to be seropositive after four months (OR=69.2). Age above 70 years and cough, as reported during the first survey, were also strongly associated with persistent anti-NC IgG levels.

\section{Discussion}

Hereby, we report the results of a repeated serosurvey conducted in five municipalities in the AP of Trento, located in northern Italy ${ }^{14}$. One of the main findings of the second survey, conducted on a large population of initially seropositive individuals, consisted in the rapid decrease of antibodies against the SARS-CoV-2 nucleocapsid. Of the 1159 participants, $41.1 \%$ resulted seronegatives by 4 months after the first evaluation. Surprisingly, when we tested the NC-negative serum samples for antibodies directed against the spike protein, we found different results, with most patients still showing seropositivity. To better understand and explain these findings, we evaluated the presence of neutralizing antibodies in a subgroup of previously anti-NC seropositive individuals and found that almost all the sera positives for antibodies against the spike protein were able to neutralize the virus entry into cell lines in vitro.

Correlates of protection have been identified for many viral infections. These correlates are usually based on a specific level of antibodies induced by vaccination or natural infection that significantly reduces the risk of (re-)infection. For some viral infections and vaccines, the kinetic of the antibody response is also known, allowing for a prediction of how long protection will persist ${ }^{15}$.

Previous studies had shown conflicting results. Studies conducted on a smaller number of individuals and/or clinical series reported a decay of neutralizing antibody levels 2 months after infection ${ }^{4,5}$. These results appear to be consistent with those obtained for other human coronaviruses, such as NL63, 229E, OC43, and HKU1, showing a rapid decay of antibodies directed against the nucleocapsid protein ${ }^{16}$. However, other studies showed different results, with high $\mathrm{IgG}$ levels after several months ${ }^{7-9,17}$. The inconsistency in the results of previous studies could be explained by differences in the study populations (i.e., patients with mild vs moderate or severe disease) or in the use of different methods (i.e., detection of antibodies directed against the nucleocapsid vs whole spike or the receptor binding domain of the spike) ${ }^{4}$. More recently, Seow et al. ${ }^{18}$ described the longitudinal decline of antibody responses in SARS-CoV-2 infection in sequential sera collected up to 94 days from the onset of symptoms of 65 COVID-19 patients.

In a longitudinal study of RT-PCR confirmed COVID-19 cases, the participants showed a wide range of antibody responses, and a decline in antibodies levels and virus neutralization was 
medRxiv preprint doi: https://doi.org/10.1101/2020.11.11.20229062; this version posted November 16,2020 . The copyright holder for this preprint (which was not certified by peer review) is the author/funder, who has granted medRxiv a license to display the preprint in It is made available under a CC-BY-NC-ND 4.0 International license.

observed within three months of the onset of symptoms ${ }^{18}$. For those who developed a low neutralizing antibody response (ID50 100-300) the titers could return to baseline over a relatively short period, whereas those who developed a robust neutralizing antibody response maintained titers $>1000$ despite the initial decline ${ }^{18}$. The decline of protective antibodies might be explained, to some extent, by the sporadic COVID-19 reinfection that have been reported ${ }^{19-21}$. In a more recent study, detectable neutralizing antibody responses were detected for several months after infection ${ }^{17}$.

To this regard, animal models show that SARS-CoV-2 infection protect from re-infection for at least some time $\mathrm{e}^{22,23}$. This protection appears to be more pronounced in the lower respiratory tract rather than in the upper respiratory tract ${ }^{23}$.

The types of antibody response may also play a role. Atyeo et $\mathrm{al}^{24}$, showed that a predominant humoral response to nucleocapsid protein is associated with poor outcome in patients admitted to hospital, compared to response to spike protein.

Most vaccine candidates elicit responses to $\mathrm{S}$ rather than NC protein. Measuring antibodies to $\mathrm{S}$ will therefore indicate whether there has been a good response. To this regard, our findings are in good agreement with the study by Wajnberg and colleagues showing that antibody responses to the $S$ protein correlate significantly with SARS-CoV-2 neutralization ${ }^{17}$.

Before drawing conclusions, strengths and limits should be mentioned. Firstly, only $17.3 \%$ of individuals did not participate in the survey, thus the refusal rate was low and the possibility of a selection bias was minimized. Secondly, the study was repeated approximately 4 months after the first test; however, a proportion of the participants was apparently asymptomatic and others reported having had symptoms suggestive of COVID-19 sometime before the survey. Thus, the 4 months represent the minimum interval of time elapsed between the virtual date of infection and the second test. Thirdly, although the serological assay we used is assumed to have high sensitivity and specificity, the occurrence of some false positive or false negative results influencing the reliability and consistency of the results could not be completely ruled out.

In conclusion, we found a general antibody decay over time, with a relatively high proportion of initially SARS-CoV-2 seropositive individuals losing their anti-nucleocapsid antibodies by 4 months after the first positive test. However, most of these individuals still had neutralizing antispike IgG antibodies, suggesting a potential long-term duration of protective immune response. This finding may have important implications in the choice of the target for antibodies persistence over the time together with the potential effectiveness and long-term protection of immune responses induced by vaccines and on herd immunity. Further studies are needed to understand whether 
medRxiv preprint doi: https://doi.org/10.1101/2020.11.11.20229062; this version posted November 16, 2020. The copyright holder for this preprint (which was not certified by peer review) is the author/funder, who has granted medRxiv a license to display the preprint in It is made available under a CC-BY-NC-ND 4.0 International license.

persistence of anti-spike, potentially neutralizing antibodies, is actual correlates of long-term protection.

\section{Acknowledgments}

The authors would like to thank the study's participants.

The authors thank the Serosurvey Study Group for COVID-19 in the AP of Trento: Mattevi Elisabetta, Dalla Valle Lorenza, Endrizzi Luca, Pecoraro Lucia, Varesco Andrea, Brida Elisa, Daldoss Alessia, Sebis Claudia, Bruno Zanon, Mauro Bandera, Laboratory Dept., APSSTrento; Riccardo Flavia and Patrizio Pezzotti, Dept. Infectious Diseases, Istituto Superiore di Sanità; Pocher Massimo, Sannicolò Renzo, Manica Andrea, Fogarolli Angela E-healthcare Solution Service, APSS Trento;Maroni Veronica, Chizzola Elisa Privacy Office, APSS Trento; Sforzin Simona Primary Care Director APSS Trento, and the entire staff of primary care involved in the study.

Funds: APSS sustained the expenses for the IgG assays on collected sera.

Figure 1. Distribution of the IgG values against SARS-CoV-2 nucleocapsid in the first (grey) and in the second (black) serosurvey.

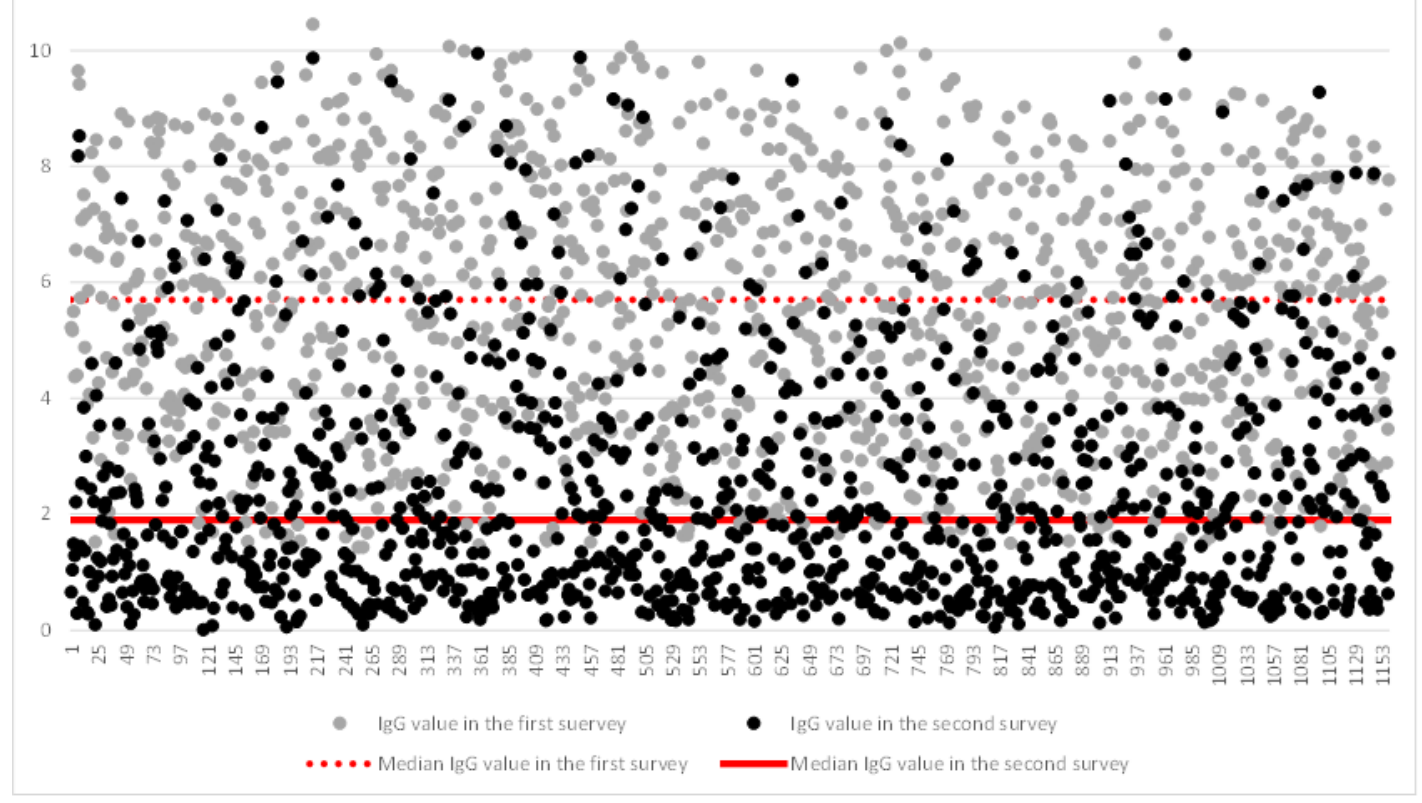


medRxiv preprint doi: https://doi.org/10.1101/2020.11.11.20229062; this version posted November 16, 2020. The copyright holder for this preprint (which was not certified by peer review) is the author/funder, who has granted medRxiv a license to display the preprint in It is made available under a CC-BY-NC-ND 4.0 International license .

Figure 2. Median of the IgG values against SARS-CoV-2 nucleocapsid in the first and second survey by IgG positivity groups.

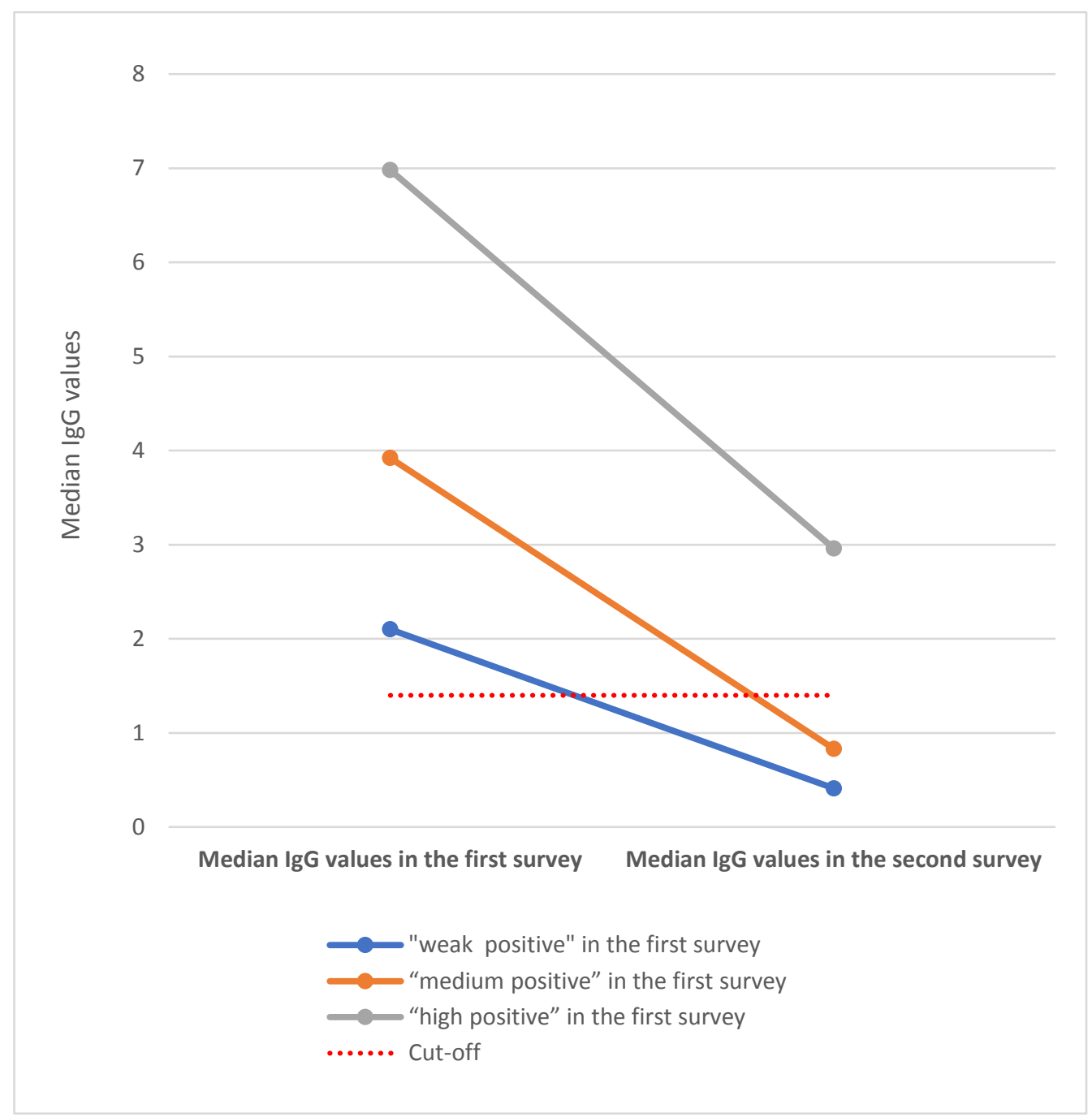


medRxiv preprint doi: https://doi.org/10.1101/2020.11.11.20229062; this version posted November 16, 2020. The copyright holder for this preprint (which was not certified by peer review) is the author/funder, who has granted medRxiv a license to display the preprint in It is made available under a CC-BY-NC-ND 4.0 International license

Figure 3 Percentage of anti-spike (S1/S2) IgG antibodies on retested anti-NC IgG negative sera.

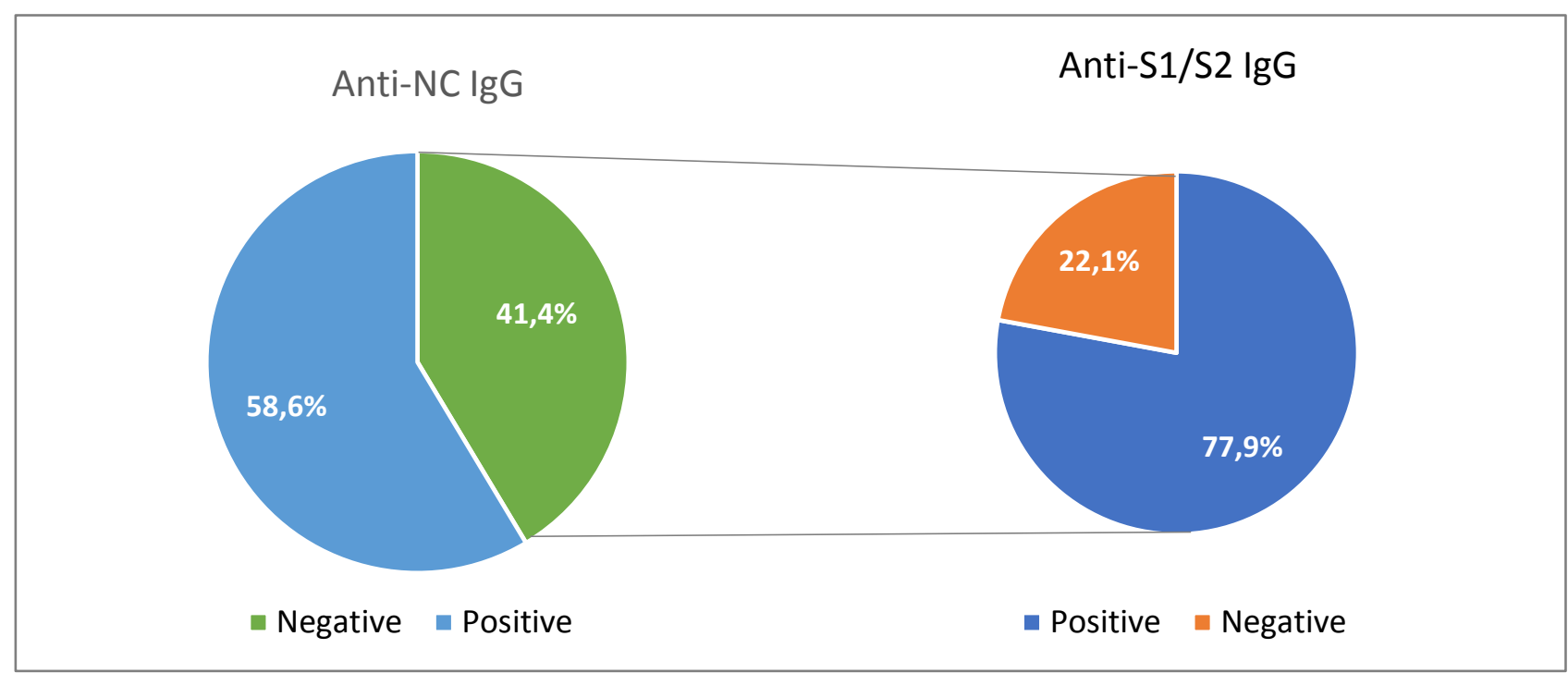

Figure 4. Comparisons between serology and functional neutralization assay. 
medRxiv preprint doi: https://doi.org/10.1101/2020.11.11.20229062; this version posted November 16, 2020. The copyright holder for this preprint (which was not certified by peer review) is the author/funder, who has granted medRxiv a license to display the preprint in It is made available under a CC-BY-NC-ND 4.0 International license .

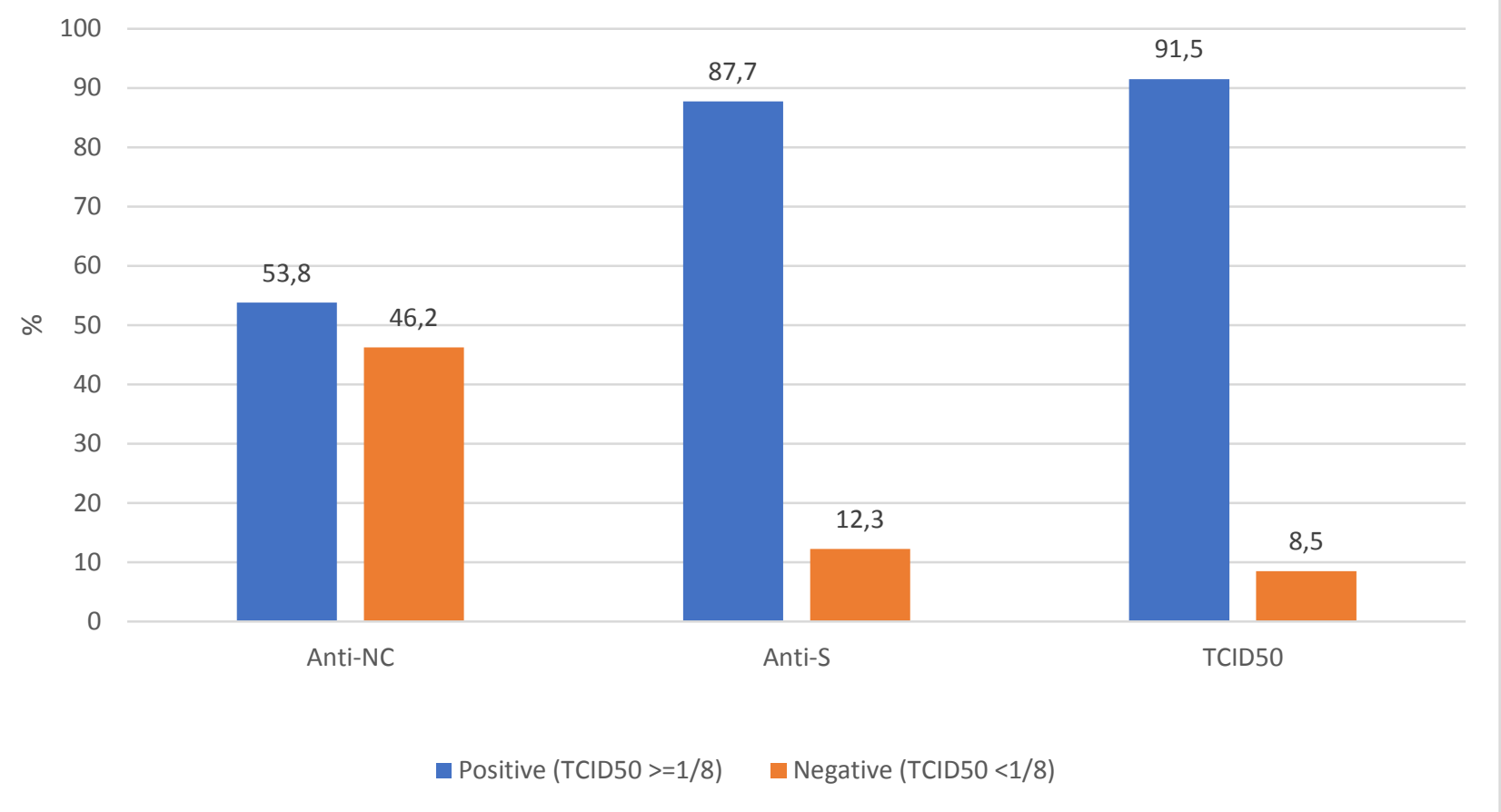

Table 1. Concordance between IgG against NC and S proteins and neutralization activity.

\begin{tabular}{|c|c|c|c|c|c|c|c|c|}
\hline & \multirow{2}{*}{ Anti-S + } & \multirow{2}{*}{ Anti-S - } & \multirow{2}{*}{ p-value* } & Agreement & \multirow{2}{*}{$\operatorname{TCID} 50 \geq 1 / 8$} & \multirow{2}{*}{ TCID50 $<1 / 8$} & \multirow{2}{*}{ p-value* } & \multirow{2}{*}{$\begin{array}{c}\text { Agreement } \\
\text { Kappa; p-value }\end{array}$} \\
\hline & & & & Kappa; p-value & & & & \\
\hline Anti-NC + & 52 & 5 & \multirow{2}{*}{$<0.0001$} & $56.6 \%$ & 53 & 4 & \multirow{2}{*}{$<0.0001$} & $54.7 \%$ \\
\hline Anti-NC - & 41 & 8 & & $K=0.08 ; p=0.1186$ & 44 & 5 & & $K=0.03 ; p=0.2787$ \\
\hline Anti-S + & & & & & 92 & 1 & \multirow{2}{*}{0.1025} & $94.3 \%$ \\
\hline Anti-S - & & & & & 5 & 8 & & $K=0.70 ; p<0.0001$ \\
\hline
\end{tabular}

* McNemar test

Table 2. Factors associated with seropositivity (multivariable logistic regression model).

\begin{tabular}{|l|r|r|r|}
\hline Variables & OR & \multicolumn{2}{|c|}{$\mathbf{9 5 \%}$ CI } \\
\hline Gender & & & \\
\hline Female & Ref & & \\
\hline Male & 1,80 & 1,26 & 2,56 \\
\hline
\end{tabular}


medRxiv preprint doi: https://doi.org/10.1101/2020.11.11.20229062; this version posted November 16, 2020. The copyright holder for this preprint (which was not certified by peer review) is the author/funder, who has granted medRxiv a license to display the preprint in It is made available under a CC-BY-NC-ND 4.0 International license .

\begin{tabular}{|l|r|r|r|}
\hline Age group (years) & Ref & & \\
\hline$<\mathbf{2 0}$ & 0,61 & 0,30 & 1,26 \\
\hline $\mathbf{2 0 - 2 9}$ & 0,70 & 0,33 & 1,47 \\
\hline $\mathbf{3 0 - 3 9}$ & 0,99 & 0,52 & 1,90 \\
\hline $\mathbf{4 0 - 4 9}$ & 1,29 & 0,68 & 2,44 \\
\hline $\mathbf{5 0 - 5 9}$ & 1,30 & 0,68 & 2,48 \\
\hline $\mathbf{6 0 - 6 9}$ & 5,09 & 2,30 & 11,24 \\
\hline $\mathbf{7 0 +}$ & & & \\
\hline Anti-NC IgG positivity group in the first serosurvey & Ref & & \\
\hline Weak & 2,29 & 1,16 & 4,55 \\
\hline Moderate & 69,23 & 35,84 & 133,72 \\
\hline High & & & \\
\hline Cough & Ref & & \\
\hline No & 2,05 & 1,16 & 3,63 \\
\hline Yes & \multicolumn{3}{|l}{} \\
\hline
\end{tabular}

\section{References}

1. Gidari A, Nofri M, Saccarelli L, et al. Is recurrence possible in coronavirus disease 2019 (COVID-19)? Case series and systematic review of literature. Eur J Clin Microbiol Infect Dis 2020; published online October 10. DOI: 10.1007/s10096-020-04057-6.

2. Channappanavar R, Zhao J,Perlman $S$. T cell-mediated immune response to respiratory coronaviruses. Immunol Res. 2014; 59(1): 118-128. doi: 10.1007/s12026-014-8534-Z

3. Li-Ping Wu, Nai-Chang Wang, Yi-Hua Chang, Xiang-Yi Tian, Dan-Yu Na, Li-Yuan Zhang, Lei Zheng, Tao Lan, Lin-Fa Wang, and Guo-Dong Liang. Duration of Antibody Responses after Severe Acute Respiratory Syndrome. Emerg Infect Dis. 2007 Oct; 13(10): 1562-1564. doi: 10.3201/eid1310.070576

4. Ibarrondo FJ, Fulcher JA, Goodman-Meza D, et al. Rapid decay of anti-SARS-CoV-2 antibodies in persons with mild COVID-19. N Engl J Med 2020; 383:1085-1087. DOI: 10.1056/NEJMc2025179.

5. Long QX, Tang XJ, Shi QL, et al. Clinical and immunological assessment of asymptomatic SARS-CoV-2 infections. Nat Med 2020; 26: 1002-1204. DOI: 10.1038/s41591-020-0965-6.

6. Grifoni A, Weiskopf D, Ramirez SI, et al. Targets of T-cell responses to SARS-CoV-2 coronavirus in humans with COVID-19 disease and unexposed individuals. Cell 2020; 181:1489-1501.e15. DOI: 10.1016/j.cell.2020.05.015.

7. Wu J, Liang B, Chen C, et al. SARS-CoV-2 infection induces sustained humoral immune responses in convalescent patients following symptomatic COVID-19. medRxiv 2020; 2020.07.21.20159178; DOI: https://doi.org/10.1101/2020.07.21.20159178.

8. Bölke E, Matuschek C, Fischer JC. Loss of Anti-SARS-CoV-2 Antibodies in Mild Covid19. N Engl J Med 2020; 383:1694-1695. DOI: 10.1056/NEJMc2027051.

9. Yang OO, Ibarrondo FJ. Loss of Anti-SARS-CoV-2 Antibodies in Mild Covid-19. Reply. N Engl J Med 2020; 383: 1697-1698. DOI: 10.1056/NEJMc2027051.

10. Deming D, Sheahan T, Heise M, et al. Vaccine efficacy in senescent mice challenged with recombinant SARS-CoV bearing epidemic and zoonotic spike variants. PLoS Medicine 2006; 3: e525. DOI: 10.1371/journal.pmed.0030525

11. Amanat F, Krammer F. SARS-CoV-2 Vaccines: Status Report. Immunity 2020; 52: 583589. DOI: 10.1016/j.immuni.2020.03.007 
medRxiv preprint doi: https://doi.org/10.1101/2020.11.11.20229062; this version posted November 16,2020 . The copyright holder for this preprint (which was not certified by peer review) is the author/funder, who has granted medRxiv a license to display the preprint in It is made available under a CC-BY-NC-ND 4.0 International license.

12. Premkumar L, Segovia-Chumbez B, Jadi R, et al. The receptor binding domain of the viral spike protein is an immunodominant and highly specific target of antibodies in SARS-CoV2 patients. Sci Immunol 2020; 5: eabc 8413. DOI: 10.1126/sciimmunol.abc8413

13. Wang, C., Li, W., Drabek, D. et al. A human monoclonal antibody blocking SARS-CoV-2 infection. Nat Commun 2020; 11: 2251. DOI: 10.1038/s41467-020-16256-y

14. Stefanelli P, Bella A, Fedele G, et al. Prevalence of SARS-CoV-2 IgG antibodies in an area of North-eastern Italy with a high incidence of COVID-19 cases: a population-based study. Clin Microbiol Infect; provisional decision for final publication.

15. Jeyanathan M, Afkhami S, Smaill F, Miller MS, Lichty BD, Xing Z. Immunological considerations for COVID-19 vaccine strategies. Nat Rev Immunol 2020;20: 615-632. DOI: 10.1038/s41577-020-00434-6.

16. Edrige AWD, Kaczorowska J, Hoste ACR, et al. Seasonal coronavirus protective immunity is short-lasting. Nat Med 2020 Published online September 14. DOI: 10.1038/s41591-0201083-1.

17. Wajnberg A, Amanat F, Firpo A, et al. Robust neutralizing antibodies to SARS-CoV-2 infection persist for months. Science. 2020; eabd7728; published online October 28. DOI: 10.1126/science.abd7728. Epub ahead of print. PMID: 33115920.

18. Seow J, Graham C, Merrick B, et al. Longitudinal evaluation and decline of antibody responses in SARS-CoV-2 infection. medRxiv 2020; 2020.07.09.20148429. DOI: https://doi.org/10.1101/2020.07.09.20148429

19. To KK, Hung IF, Chan KH, et al. Serum antibody profile of a patient with COVID-19 reinfection. Clin Infect Dis 2020; 20ciaa1368; published online September 23. DOI: 10.1093/cid/ciaa1368.

20. Gupta V, Bhoyar RC, Jain A, et al. Asymptomatic reinfection in two healthcare workers from India with genetically distinct SARS-CoV-2. Clin Infect Dis 2020; ciaa1451; published online September 23. DOI: 10.1093/cid/ciaa1451.

21. Tillett RL, Sevinsky JR, Hartley PD, et al. Genomic evidence for reinfection with SARSCoV-2: a case study. Lancet Infect Dis. 2020; S1473-3099(20)30764-7; published online 12 October. Doi: 10.1016/S1473-3099(20)30764-7.

22. Chandrashekar A, Liu J, Martinot AJ, et al. SARS-CoV-2 infection protects against rechallenge in rhesus macaques. Science 2020; 369: 812-817. DOI: 10.1126/science.abc4776.

23. Imai M, Iwatsuki-Horimoto K, Hatta M, et al. Syrian hamsters as a small animal model for SARS-CoV-2 infection and countermeasure development. Proc Natl Acad Sci U S A 2020; 117: 16587-16595. DOI: 10.1073/pnas.2009799117.

24. Atyeo C, Fischinger S, Zohar T, et al. Distinct early serological signatures track with SARSCoV-2 survival. Immunity 2020; 53:524-532.e4. DOI: 10.1016/j.immuni.2020.07.020.

\section{Conflict of interest disclosure}

The authors declare no conflict of interest related to this study. 
medRxiv preprint doi: https://doi.org/10.1101/2020.11.11.20229062; this version posted November 16, 2020. The copyright holder for this preprint (which was not certified by peer review) is the author/funder, who has granted medRxiv a license to display the preprint in It is made available under a CC-BY-NC-ND 4.0 International license .

\section{Authors contribution}

P.S., A.B. together with A.F. were responsible for the conception and design of the study; G.F. and P.S. coordinated the analysis on sera; P.L., P. V., A. N., A. C., I.S., M. S., I. S., S. F., E. B., C.F. performed the analysis on sera; S.P. M.G.Z., G.B., R.M., P.P.B., organized the samples and data collection; A.B. performed the statistical analysis; S. B. and G. R. help in the discussion of data; G.R. revised critically the manuscript; P.S. wrote the manuscript. All the authors revised and approved the manuscript. 